\title{
First Report of Redeposited Cretaceous Radiolarians in the Eocene Sand-Shale Member of Zhepure Formation, Tüna, Yadong, Tibet
}

\author{
Xinfa Li1,2, Guobiao Li ${ }^{1,2}$ \\ ${ }^{1}$ State Key Laboratory of Environmental Geology and Biogeology, China University of Geosciences, Beijing, China \\ ${ }^{2}$ School of Earth Sciences and Resources, China University of Geosciences, Beijing, China \\ Email:1030193727@qq.com, liguobiao@cugb.edu.cn
}

How to cite this paper: $\mathrm{Li}, \mathrm{X} . \mathrm{F}$. and $\mathrm{Li}$, G.B. (2019) First Report of Redeposited Cretaceous Radiolarians in the Eocene Sand-Shale Member of Zhepure Formation, Tüna, Yadong, Tibet. Open Journal of Geology, 9, 566-568.

https://doi.org/10.4236/ojg.2019.910043

Received: August 15, 2019

Accepted: September 17, 2019

Published: September 20, 2019

Copyright ( 2019 by author(s) and Scientific Research Publishing Inc. This work is licensed under the Creative Commons Attribution International License (CC BY 4.0).

http://creativecommons.org/licenses/by/4.0/

\begin{abstract}
Cretaceous radiolarians were firstly reported from the Eocene Sand-Shale Member of Zhepure Formation in the Gulupu section, Tüna, Yadong, Tibet. In spite of poor preservation, 24 species of 14 radiolarian genera have still been identified, clearly indicating an age, ranging from early Aptian-Maastrichtian, and therefore should have occurred in the Eocene as a result of redeposition. The study of the stratigraphic origin of these radiolarians will shed light on the paleoenvironment and late evolutionary history of the Tibet-Tethys.
\end{abstract}

\section{Keywords}

Cretaceous, Redeposited Radiolarians, Eocene, Zhepure Formation, Paleoenvironment, Yadong

\section{Radiolarian Biostratigraphy}

A certain number of radiolarians were obtained in the Eocene strata of Gulupu section, based on the previous studies on Cretaceous radiolarians in Tibet [1] [2] [3] [4], and other areas [5] [6], 24 species of 14 genera were identified, which provides an age of middle to late Cretaceous. The important elements (Figure 1) include Turbocapsula fugitive O'Dogherty, early Aptian to early Albian; Cryptamphorella conara (Foreman), Albian to late Maastrichtian; Pessagnobrachia irregularis (Squinabol), middle Albian to middle Cenomanian; Acaeniotyle umbilicate (Rust), late Campanian; Holocryptocanium tuberculatum Dumitrica, late Cenomanian; Xitus spicularius (Aliev), middle Albian; Stichomitra compsa Foreman, Maastrichtian; Pseudodictyomitra carpatica (Lozyniak), 


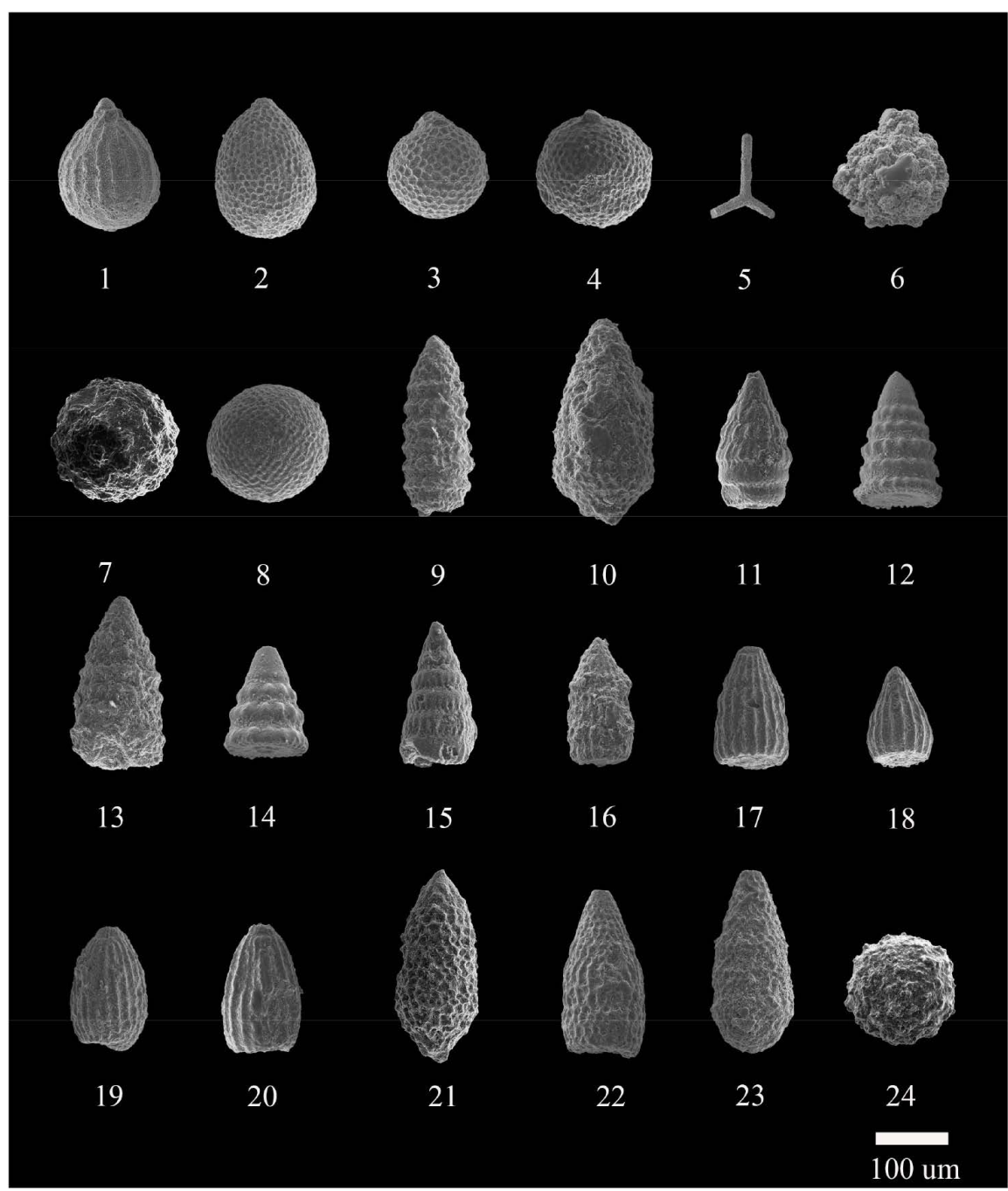

Figure 1. Scanning electron micrographs of reworked radiolarians in the Gulupu section. 1. Turbocapsula costata (Wu); 2. T. fugitive O’Dogherty; 3. Cryptamphorella conara (Foreman); 4. C. sphaerica (White); 5. Pessagnobrachia irregularis (Squinabol); 6. Acaeniotyle umbilicate (Rust); 7. Holocryptocanium tuberculatum Dumitrica; 8. H. sp.; 9. Xitus spicularius (Aliev); 10. Stichomitra compsa Foreman; 11. Pseudodictyomitra carpatica (Lozyniak); 12. P. hornatissima (Squinabol); 13. P. nuda (Schaaf); 14. P. pachicostata (Wu and Li); 15. Dictyomitra communis (Squinabol); 16. D. montisserei (Squinabol); 17. D. multicostata Zittel; 8. Thanarla brouweri (Tan); 19. T. conica (Squinabol); 20. T. veneta (Squinabol); 21. Distylocapsa veneta (Squinabol); 22. Lithostrobus litus Forman; 23. Amphipyndax stockii (Campbell and Clark); 24. Praeconocaryomma californiaensis Pessagno.

early Aptian; P. nuda (Schaaf), early Aptian; P. pachicostata (Wu and Li), Turonian; Dictyomitra communis (Squinabol), late Aptian; middle Albian; D. multicostata Zittel, early Turonian; Lithostrobus litus Forman, late Cretaceous; Thanarla conica (Squinabol), Middle Albian; T. veneta (Squinabol), late Albian to Turonian; Amphipyndax stockii (Campbell and Clark), Campanian; Distylocapsa veneta (Squinabol), late Albian to middle Cenomanian and Praeconocaryomma californiaensis Pessagno, Coniacian-Santonian. 
During Eocene, there was a residual basin in Yadong area [7]. According to the plate tectonic background and stratigraphic characteristics of Yadong and adjacent areas, it is inferred that the redeposited radiolarian should come from the underlying Cretaceous strata in the study area and adjacent areas, which redeposited in Eocene residual sea basin after weathering, erosion and transportation.

\section{Acknowledgements}

This work was supported by the National Natural Science Foundation of China (41272030), UNESCO/IUGS/IGCP 679 and 608, and the National Basic Research Program of China (2012CB822001).

\section{Conflicts of Interest}

The authors declare no conflicts of interest regarding the publication of this paper.

\section{References}

[1] Li, G.B., Wan, X.Q., Liu, W.C., Bucher, H., Li, H.S. and Goudemand, N. (2009) A New Cretaceous Age for the Saiqu "Mélange," Southern Tibet: Evidence from Radiolaria. Cretaceous Research, 30, 35-40. https://doi.org/10.1016/j.cretres.2008.03.001

[2] Li, G.B., Xie, D., Wan, X.Q., Han, H.D. and Chen, P.L. (2009) Discovery of Radiolaria from the Zongzhuo Formation in Tianba, Kangmar, Tibet and Its Age Implication. Acta Geologica Sinica, 83, 853-859. https://doi.org/10.1111/j.1755-6724.2009.00123.x

[3] Wang, T.Y., Li, G.B., Li, X.F., Niu, X.L., Zhang, J.B. and Xue, S. (2016) Radiolarian Assemblage from the Mélange in the Southern Margin to Yarlung-Zangbo Suture and its Geological Significance. Geoscience, 30, 445-453.

[4] Liang, Y.P. (2012) Cretaceous-Paleocene Radiolarian Fauna in Saga-Zhongba, Southwestern Tibet: Implications for the Evolution of Neo-Tethys. Ph.D. Thesis, China University of Geosciences, Wuhan.

[5] O’Dogherty, L. (1994) Biochronology and Paleontology of Mid-Cretaceous Radiolarians from Northern Apennines (Italy) and Betic Cordillera (Spain). Section des sciences de la terre, Université de Lausanne, Lausanne, Suisse.

[6] Bak, M. (1995) Mid Cretaceous Radiolaria from the Pieniny Klippen Belt, Carpathians, Poland. Cretaceous Research, 16, 1-23. https://doi.org/10.1006/cres.1995.1001

[7] Li, X.F. and Li, G.B. (2019) The Discovery of Eocene Radiolarian Fauna from Tüna, Yadong, Southern Tibet, China. Acta Geologica Sinica, 93, 265-267. https://doi.org/10.1111/1755-6724.14158 